\title{
The Requirement of the Normal Rat for Pteroylglutamic Acid
}

\author{
By SYLVIA J. DARKE AND C. WHITE \\ Department of Physiology, University of Birmingham
}

(Received I9 September 1949)

Many workers on the subject of pteroylglutamic-acid (PGA) deficiency in the rat have obtained data about the requirement of the rat for this vitamin; but so far the emphasis has been on the therapeutic dose required to correct a given deficiency rather than on the amount necessary for maintenance. Figures for the normal requirement are needed as a guide in the preparation of certain purified diets for rats. They are also necessary in another connexion. Davidson \& Girdwood (1948), Wilkinson (1948) and other clinical workers have reported that, when PGA is used in the treatment of pernicious anaemia, the dose has often to be increased progressively in order to maintain a constant level of haemoglobin. This is an unusual response to a vitamin, and it is therefore desirable to find whether any comparable effect can be seen during the maintenance of rats with pteroylglutamic acid. As a preliminary to the solution of this problem, the present paper describes the collection of some data on the normal requirement of the rat for this vitamin. In the course of the work we have necessarily made observations on the syndrome of pteroylglutamic-acid deficiency. This syndrome has been described by many workers, including Spicer, Daft, Sebrell \& Ashburn (1942), Endicott, Daft \& Ott (1945) and Asenjo (1948), but we wish to make further comments on the signs.

\section{METHODS}

Plan of experiment. 'Two separate groups of experiments were carried out. In the first group we tried the effect of varying doses of pteroylglutamic acid on twenty-two albino rats, and concluded that a dose of $16 \mu \mathrm{g}$./week would be adequate for most of the animals. In a second group of experiments we then gave this dosage a more extended trial, using eighteen hooded rats and thirty-one albinos. The rats were housed in metabolism cages. They varied from 4 to 6 weeks of age at the beginning of the experiment and were weighed twice a week.

Basic diet. The basic diet was made up in the following relative quantities: vitaminfree casein (Glaxo Laboratories Ltd.) 24 g., sucrose $65 \mathrm{~g}$., peanut oil $4 \mathrm{~g}$., cod-liver oil 2 g., salt mixture $4 \mathrm{~g}$., succinylsulphathiazole $\mathrm{I}$ g., aneurin $0.4 \mathrm{mg}$., riboflavin $0.8 \mathrm{mg}$., nicotinic acid $5 \mathrm{mg}$., calcium pantothenate $4 \mathrm{mg}$., pyridoxin $0.5 \mathrm{mg}$., inositol $16 \mathrm{mg}$., choline chloride $150 \mathrm{mg}$., biotin $5 \mu \mathrm{g}$,, and menaphthone (2-methyl-I:4naphthoquinone) $0.75 \mathrm{mg}$. The salt mixture consisted of: $\mathrm{CaCO}_{3} 300 \mathrm{~g}$., $\mathrm{K}_{2} \mathrm{HPO}_{4}$ 322.5 g., $\mathrm{CaHPO}_{4} .2 \mathrm{H}_{2} \mathrm{O} 75 \mathrm{~g}$., $\mathrm{MgSO}_{4} .7 \mathrm{H}_{2} \mathrm{O} 102 \mathrm{~g}$., $\mathrm{NaCl} 167.5 \mathrm{~g}$., ferric citrate $\left(\mathrm{C}_{6} \mathrm{H}_{5} \mathrm{O}_{7} \mathrm{Fe} .6 \mathrm{H}_{2} \mathrm{O}\right) 27.75 \mathrm{~g}$., $\mathrm{KI} 0.8 \mathrm{~g}$., $\mathrm{MnSO}_{4} .4 \mathrm{H}_{2} \mathrm{O} 5 \mathrm{~g}$., $\mathrm{ZnCl}_{2} 0.25 \mathrm{~g}$., and $\mathrm{CuSO}_{4} \cdot \mathrm{H}_{2} \mathrm{O} 0.3 \mathrm{~g}$. The diet was fed ad lib. It was originally planned for short experiments, and was found to be somewhat inadequate in vitamin $\mathrm{A}$ if it were stored 
for more than a few weeks; therefore supplementary cod-liver oil was given by mouth to the rats in some of the experiments. Pteroylglutamic acid was injected subcutaneously twice a week in the form of Folvite (I.ederle Laboratories Ltd.), diluted with distilled water. Dilute solutions of this preparation deteriorate even when precautions are taken to prevent undue exposure to light. Certain experiments had to be rejected for this reason, and the dilutions are now made up just before injection.

Blood counts. Total white cell and differential counts were carried out fortnightly in the first set of experiments. A weight of at least $120 \mathrm{~g}$. and a granulocyte count of more than 500/cu.mm. were accepted as evidence that the dose of PGA had been adequate. In the second set of experiments we maintained the rats on the selected dose of $16 \mu \mathrm{g}$. $\mathrm{PGA} /$ week. Blood counts were made as required. When the above-mentioned criteria had been satisfied the injections were discontinued to find whether the animals would become deficient without the supplement. Some observations were also made on red blood-cell counts and haemoglobin levels. The latter were determined by the Haldane method. All blood required was drawn by pricking one of the veins in the tail. An adequate flow was regularly obtained if the tail was first heated in water to $45^{\circ}$ for about I min. A lower temperature was usually insufficient to cause vasodilation, and at higher temperatures the skin was liable to be scalded.

'The blood films were stained with Giemsa, and a total of 400 leucocytes was classified for each differential count, except in a few instances where an exceptionally low total count made the classification of 400 cells both tedious and unnecessary. The total leucocyte counts were based on the enumeration of approx. $45^{\circ}$ cells, but were otherwise carried out with standard technique.

\section{RESLLTS}

Syndrome of deficiency. After about 5 weeks on a diet inadequate in pteroylglutamic acid the rats failed to maintain a normal rate of growth, and then began to lose weight and develop diarrhoea. An early sign of deficiency was the so-called chromodacryorrhoea, or 'bloody tears', that is the loss in the tears of a red pigment, believed to consist of porphyrins originating in the Harderian gland. The pigment caused a reddishbrown incrustation which appeared first around the eyes and nostrils, and which was subsequently found on the front paws and then on the fur of the head and back. In addition, the fur became rough and, if the animal survived long enough, bald patches appeared; occasionally there was an almost complete loss of hair. When the condition became severe the animals developed photophobia; they then rested in a hunched position and resented handling.

An occasional, but important, development was the occurrence of ulcers in the mucous membrane of the tongue or oral cavity. The accompanying infection sometimes progressed to a stage where the whole face became swollen and tender. On one occasion, in the course of a routine blood count, it was noted that bacteria were present in the blood in large numbers.

In some animals haematuria occurred, and at post-mortem crystalline renal calculi were observed. This complication was most likely to occur if the animals were maintained on the experimental diet for more than 4 months, but we have no evidence that 
this is a symptom of folic-acid deficiency, and regard it as a toxic reaction following the absorption of succinylsulphathiazole, and perhaps free sulphathiazole, from the diet.

In a few animals priapism developed just before death, and was considered to be an accompaniment of the blood dyscrasia.

The changes in the blood picture were characteristic. The first obvious effect was a decrease in the granulocytes which, if the deficiency was not treated, invariably progressed towards agranulocytosis. After the granulocytes decreased there was usually a fall in the number of lymphocytes. We have arbitrarily decided that granulocytopenia existed if there were less than 500 granulocytes/cu.mm. blood. The figures

'Table I. Comparison of granulocyte and lymphocyte levels found in 354 samples of blood from rats kept for varying periods of time on a diet deficient in pteroylglutamic acid

\begin{tabular}{|c|c|c|c|}
\hline \multirow{2}{*}{$\begin{array}{l}\text { Granulocytes/cu.mm. } \\
\text { blood }\end{array}$} & \multirow{2}{*}{$\begin{array}{l}\text { Total no. of } \\
\text { samples }\end{array}$} & \multicolumn{2}{|c|}{$\begin{array}{l}\text { Samples showing fewer } \\
\text { lymphocytes than } 500 / \text { cu.mm. }\end{array}$} \\
\hline & & No. & Percentage \\
\hline $\begin{array}{r}0-200 \\
201-500\end{array}$ & $\begin{array}{l}79 \\
58\end{array}$ & $\begin{array}{l}47 \\
10\end{array}$ & $\begin{array}{l}59.5 \\
17.2\end{array}$ \\
\hline $501-1000$ & 87 & 9 & $10 \cdot 3$ \\
\hline$>1000$ & I 30 & 3 & $2 \cdot 3$ \\
\hline
\end{tabular}

in 'Table I show that granulocytopenia was more common than lymphocytopenia; fifty-seven samples showed both granulocytopenia and lymphocytopenia; eighty showed granulocytopenia alone; and only twelve showed lymphocytopenia alone. When there was a decrease in both granulocytes and lymphocytes, the former cells almost invariably decreased earlier. A characteristic finding in many advanced cases of deficiency was the presence of immature granulocytes in the peripheral blood. It frequently happened in such cases that the only granulocytes present were of the immature type.

We have not consistently looked for anaemia, because we found in the early stages of the work that it was an unreliable sign of deficiency, since the haemoglobin level could be normal in animals that were grossly deficient. We have at times, however, observed anaemia, and it was common to note in the blood films such qualitative evidence of its presence as polychromasia, the presence of target cells and an increase in normoblasts. The figures in Table 2 show, nevertheless, that it was rare to find gross anaemia, even in animals that had become so deficient in folic acid as to develop low granulocyte counts. Thus, of sixteen deficient rats examined, six had a haemoglobin percentage of more than 100 , and ten had a percentage greater than 90 . The contrast between the relatively mild changes in the red cells and the pronounced effect on the granulocytes is further shown by the fact that the haemoglobin percentage was greater than 90 in four out of five animals that had agranulocytosis and were in extremis.

'The syndrome of pteroylglutamic-acid deficiency may be induced by the use of the diet already described, then cured by the administration of pteroylglutamic acid, and subsequently induced again by discontinuing the supplement of pteroylglutamic acid. The data shown in Table 3 were obtained on a rat which developed the deficiency syndrome on three separate occasions over a period of $4 \frac{1}{2}$ months. On the first occasion 
Table 2. Incidence of anaemia in rats suffering from deficiency of pteroylglutamic acid

\begin{tabular}{|c|c|c|c|}
\hline Colony no. of rat & $\begin{array}{l}\text { Granulocytes/ } \\
\text { cu.mm. blood }\end{array}$ & $\begin{array}{c}\text { Erythrocytes } \\
\text { (millions/cu.mm. } \\
\text { blood) }\end{array}$ & $\begin{array}{r}\text { Haemogl } \\
\text { percent } \\
\text { (Haldane }\end{array}$ \\
\hline $9 R$ & 。 & $7 \cdot 1$ & - \\
\hline $15 \mathrm{aBL}$ & 0 & - & 113 \\
\hline I L & o & 13.2 & 150 \\
\hline $2 \mathrm{~L}(28 . \text { vii. } 47)^{*}$ & o & $9 \cdot 0$ & 二 \\
\hline $2 \mathrm{~L}(29 . \text { viii. } 47)^{*}$ & ० & - & $9 \mathrm{I}$ \\
\hline $2 \mathrm{~L}(18 . \times .47)^{\circ}$ & 0 & - & 91 \\
\hline $2 \mathrm{aR}$ & $\circ$ & 13.5 & 二 \\
\hline 2H (19. vii. 47)* & o & $5 \cdot I$ & 65 \\
\hline $14 \mathrm{BR}$ & 10 & $8 \cdot 5$ & 98 \\
\hline $13 \mathrm{LR}$ & 50 & - & 80 \\
\hline $26 \mathrm{R}$ & 60 & $11 \cdot 7$ & 115 \\
\hline $7 \mathrm{~B}$ & 70 & $8 \cdot 9$ & 100 \\
\hline $16 \mathrm{bR}$ & 90 & - & $5^{6}$ \\
\hline${ }_{3} \mathbf{R}$ & 90 & - & 99 \\
\hline $9 \mathrm{~L}$ & 120 & II.7 & 118 \\
\hline $6 \mathrm{H}$ & 120 & $9 \cdot 7$ & 87 \\
\hline $3 \mathrm{~L}$ & 160 & $7 \cdot 7$ & 85 \\
\hline $14 \mathrm{~L}$ & 190 & $7 \cdot 3$ & 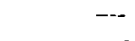 \\
\hline $16 \mathrm{bLR}$ & 220 & - & 42 \\
\hline $2 \mathrm{H}($ (Ir. vii. 47)* & 270 & $9 \cdot \mathrm{I}$ & 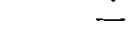 \\
\hline $15 \mathrm{aBL}$ & 390 & $7 \cdot 2$ & - \\
\hline $2 \mathrm{~L}(18 . \text { vii. } 47)^{*}$ & 440 & $9 \cdot \mathrm{I}$ & I \\
\hline
\end{tabular}

- More than one estimation was carried out using rats $2 \mathrm{H}$ and $2 \mathrm{~L}$, hence the dates of the estimations are given.

Table 3. Repeated induction of deficiency of pteroylglutamic acid in a weanling male rat. The experiment started on 4 fune 1947 and the animal died on 22 October 1947

\begin{tabular}{|c|c|c|c|}
\hline $\begin{array}{l}\text { Date } \\
\text { I } 947\end{array}$ & $\begin{array}{l}\text { Granulocytes: } \\
\text { cu.mm. blood }\end{array}$ & $\begin{array}{l}\text { Lymphocytes/ } \\
\text { cu.mm. blood }\end{array}$ & Treatment \\
\hline I1. vi & 1,260 & $8,300\}$ & \multirow{4}{*}{$\begin{array}{l}\text { Synthetic deficient diet and } \\
\text { no PGA injections }\end{array}$} \\
\hline 23. vi & 1,220 & 14,500 & \\
\hline 18. vii & 440 & & \\
\hline 28. vii & 0 & 4,400 & \\
\hline 29. vii-I. vii & - & - & Diet of rat cubes \\
\hline $\begin{array}{l}\text { 11. viii } \\
\text { 18. viii } \\
\text { 25. viii }\end{array}$ & $\begin{array}{r}1,360 \\
710 \\
0\end{array}$ & $\left.\begin{array}{r}7,900 \\
12,300 \\
5,200\end{array}\right\}$ & $\begin{array}{l}\text { Synthetic deficient diet and } \\
\text { no PGA injections }\end{array}$ \\
\hline 29. viii & ० & $4,400)$ & \multirow{7}{*}{$\begin{array}{l}\text { Synthetic deficient diet and } \\
\text { subcutaneous injection of } \\
4 \mu \mathrm{g} . \text { PGA }\end{array}$} \\
\hline I. ix & 20 &,+ 900 & \\
\hline $\begin{array}{l}\text { 5. ix } \\
8 . \text { ix }\end{array}$ & $5^{\circ}$ & 3,350 & \\
\hline $\begin{array}{l}\text { 8. ix } \\
\text { I1. ix }\end{array}$ & - & - & \\
\hline 16. ix & 1,120 & 7,900 & \\
\hline 19. ix & - & - & \\
\hline 22. ix & 1,660 & 7,500 & \\
\hline $8 . x$ & 100 & 4,300 & \multirow{2}{*}{$\begin{array}{l}\text { Synthetic deficient diet and } \\
\text { no PGA injections }\end{array}$} \\
\hline It. $x$ & $\circ$ & 1,350 & \\
\hline
\end{tabular}

it was cured by reverting to a diet of rat cubes, and on the second occasion by injections of pteroylglutamic acid. The third illness was fatal. During the periods of deficiency the animal showed the syndrome described above, and this syndrome is therefore specifically duc to the absence of pteroylglutamic acid. 
Requirement for pteroylglutamic acid. The results of the preliminary investigation have previously been briefly reported (Darke \& White, I948-9). Twenty-two animals were used, but some were treated with more than one dosage level of pteroylglutamic acid, so that there were fifty-nine tests in all. The results are shown in Table 4.

Table 4. Adequacy of various doses of pteroylglutamic acid (PGA) for the rat

Dose of PGA
$(\mu \mathrm{g} . /$ week)
$0 \cdot 5$
$2 \cdot 0$
$4 \cdot 0$
$8 \cdot 0$
$16 \cdot 0$
$32 \cdot 0$

$\begin{array}{cc}\begin{array}{c}\text { No. of animals } \\ \text { tested }\end{array} & \begin{array}{c}\text { No. of animals that } \\ \text { developed deficiency }\end{array} \\ 6 & 6 \\ 17 & 14 \\ 4 & 3 \\ 18 & 5 \\ 7 & 2 \\ 7 & 0\end{array}$

Median effective dose $=5.5 \mu \mathrm{g}$, with fiducial limits at $P=0.95$ of 3.8 and $7.8 \mu \mathrm{g} . /$ week.

The median effective dose was $5.5 \mu \mathrm{g}$./week with fiducial limits at $P=0.95$ of 3.8 and $7 \cdot 8 \mu \mathrm{g}$. $/$ week. A dose of $16 \mu \mathrm{g}$. was adequate for five out of seven animals tested, and was selected for trial on a larger group.

The results of the subsequent experiment are given in Table 5 .

Table 5. Response of forty-nine rats to a maintenance dose of $16 \mu \mathrm{g} . /$ week of pteroylglutamic acid

\begin{tabular}{|c|c|c|}
\hline Type of rat & No. tested & No. found deficient \\
\hline Albino: female & I 8 & I \\
\hline male & 13 & o \\
\hline $\begin{array}{c}\text { Hooded: female } \\
\text { male }\end{array}$ & $\begin{array}{r}3 \\
15\end{array}$ & $\begin{array}{l}0 \\
2\end{array}$ \\
\hline Total & 49 & 3 \\
\hline
\end{tabular}

The criteria used to establish deficiency were those previously mentioned. It is seen that a dose of $\mathrm{I} 6 \mu \mathrm{g}$./ week was adequate, as measured by these criteria, for about fortysix out of forty-nine of the rats.

We considered it advisable to withdraw the supplement of pteroylglutamic acid for each rat as soon as it passed the stated tests of satisfactory progress. We then continued observing the animal to ensure whether the deficiency developed. This was a precaution against the possibility that synthesis of pteroylglutamic acid in the intestine might restart after an initial delay, or that the requirements for the vitamin might become insignificant as the rats grew up. We therefore kept the animals under observation for a total period of 3-5 months. Of the forty-six animals that progressed satisfactorily on $16 \mu \mathrm{g}$./week, thirty-nine became deficient, as judged by both clinical and haematological tests, when the pteroylglutamic acid was withdrawn. The remaining seven also became deficient, as judged by loss of weight and porphyrin staining, but haematological data were not obtained for five of these animals, and in the remaining two the findings at the time of examination were not diagnostic of the deficiency state. 
Syndrome of deficiency. In the classical description of folic-acid deficiency by Spicer et al. (1942), emphasis is laid on the granulocytopenia. The authors, surprisingly, make no special mention of the lymphocytopenia which their data clearly reveal. They note that anaemia occurred, 'but with comparative infrequency'. In somc of the subsequent literature, more extensive changes in the blood cells are reported, and Swendseid, Brown, Bird \& Heinrich (1948) even refer to a reduction of all the formed elements of the blood as characteristic of the syndrome. Probably more emphasis should be placed on the order in which the various changes occur. The decrease in granulocytes comes first; the decrease in lymphocytes is later and less regular; finally, a decrease in haemoglobin and erythrocytes is uncommon, although Kodicek \& Carpenter (1948) observed it regularly when they maintained their rats in a state of chronic deficiency of pteroylglutamic acid. The order in which the various types of blood cell decrease, and the relative amounts of the decrease, are reminiscent of what happens in agranulocytosis of human beings; rats with PGA deficiency are suitable experimental animals for work on certain aspects of this condition.

The appearance of ulceration in the mouth is a further sign that we wish to emphasize, because of its occurrence in agranulocytosis as seen clinically in man. Franklin, Stokstad, Belt \& Jukes (1947) observed ulceration of the mouth in rats when PGA deficiency was induced by a chemical antagonist of the vitamin, but stated that they had never observed it when the deficiency was induced by dietary means. In our experience it was a characteristic sign of advanced deficiency.

'The significance of the increased excretion of porphyrins from the Harderian gland is unknown. Injection of acetylcholine into a normal rat causes, in the course of a few minutes, an outpouring of tears that are rich in porphyrin. We have therefore examined PGA-deficient animals for evidence of parasympathetic stimulation. The diarrhoea which these animals exhibit might be considered a symptom of such a condition. On the other hand, we failed to find any decrease in the heart rate.

Porphyrin staining is known to occur in conditions of dehydration. We have verified this, and propose to investigate the possibility that dehydration is the prime factor in causing the 'bloody tears' of PGA deficiency.

It is usually accepted that PGA deficiency, like other syndromes due to lack of vitamins, can be more readily induced in weanling rats than in older rats. We have no evidence against this, but it is worthy of note that PGA deficiency can be easily precipitated in rats of 4-6 months of age. There is no suggestion, however, that the requirement for PGA becomes progressively greater the longer the vitamin is administered.

Requirement of rat for pteroylglutamic acid. Asenjo (1948) found that the minimum therapeutic dose of pteroylglutamic acid for a rat was $30 \mu \mathrm{g}$./week. In a standard synthetic diet Sporn, Ruegamer \& Elvehjem (1947) have used $215 \mu \mathrm{g} . / \mathrm{kg}$. diet, which is approximately $16 \mu \mathrm{g}$./week, but no sulphonamides were included in the diet. Our finding that $16 \mu \mathrm{g}$./week were adequate for most rats is in harmony with the findings of Asenjo (1948) and those of Sporn et al. (1947).

Nelson \& Evans (1947) found that the requirement for PGA was greatly increased 
during pregnancy, and also that a lactating rat required up to $567 \mu \mathrm{g}$./week for a maximal effect on the weaning weight of the young. In addition to considering the possibility of physiological variations of this type one should remember that the need for PGA will vary according to the basic diet. The amount of PGA in the "vitaminfree' casein is of obvious significance in this regard. (The casein in our experiments would probably supply some $1-3 \mu \mathrm{g}$. PGA/week if the daily intake of food is assumed to be ro g.) Shehata \& Johnson (1948) found that the level of protein was especially important in determining the response to PGA. It is clear from their work that the amount of protein in the basic diet might be the deciding factor in determining whether anaemia would occur, for instance, during a state of PGA deficiency.

\section{SUMMARY}

I. Growing albino rats were maintained on a synthetic diet containing I \% succinylsulphathiazole, and varying doses of pteroylglutamic acid (PGA) were injected subcutaneously. Blood counts were made fortnightly, and a weight of at least $120 \mathrm{~g}$. and a granulocyte count of more than $500 / \mathrm{cu} . \mathrm{mm}$. were accepted as evidence that the dose of PGA had been adequate.

2. The median effective dose was $5.5 \mu \mathrm{g}$./week with fiducial limits at $P=0.95$ of 3.8 and $7.8 \mu \mathrm{g}$. $/$ week, and it was concluded that a dose of $16 \mu \mathrm{g}$./week would be adequate for most animals.

3. Growing albino rats and hooded rats were then maintained on the same diet and were given $16 \mu \mathrm{g}$. PGA/week in two subcutaneous injections. When the abovementioned criteria had been satisfied the injections were discontinued. Forty-six of the forty-nine rats subsequently showed signs of PGA deficiency.

4. No evidence was obtained that the requirement of the rat for PGA became greater the longer the vitamin was administered.

5. The syndrome of PGA deficiency in the rat is described and discussed.

\section{REFERENCES}

Asenjo, C. F. (1948). I. Nutrit. 36, 601.

Darke, S. J. \& White, C. (1948-9). Brit. Y. Nutrit. 2, ix.

Davidson, L. S. P. \& Girdwood, R. H. (1948). Lancet, 254, 360.

Endicott, K. M., Daft, F. S. \& Ott, M. (1945). Arch. Path. 40, 364.

Franklin, A. I., Stokstad, E. L. R., Belt, M. \& Jukes, T. H. (I947). F. biol. Chem. I69, 427.

Kodicek, E. \& Carpenter, K. J. (r948), Biochem. F. 43, i.

Nelson, M. M. \& Evans, H. M. (1947). Arch. Biochem. 13, 265.

Shehata, O. \& Johnson, B. C. (1948). Proc. Sac. exp. Biol., N.Y., 67, 332.

Spicer, S. S., Daft, F. S., Sebrell, W. H. \& Ashburn, L. L. (1942). Publ. Hlth Rep., Wash., 57, 1559.

Sporn, E. M., Ruegamer, W. R. \& Elvehjem, C. A. (1947). Proc. Soc. exp. Biol., N. Y., 65, 5.

Swendseid, M. E., Brown, R. A., Bird, O. D. \& Heinrich, R. A. (1948). Arch. Biochem. 16, 367.

Wilkinson, J. F. (1948). Brit. med. F. i, 771 . 